\title{
Challenges of PE Teachers to Educational Technologies in New Normal: The Changing Role of Teachers
}

\author{
Saramie S. Belleza ${ }^{1}$, Ronald D. Ompoc ${ }^{2}$, Catherine F. Vestil ${ }^{3}$ \\ ${ }^{1}$ Associate Professor 1, UM Tagum College, Tagum City, Philippines \\ ${ }^{2}$ Teacher III, Department of Teacher Education, Nasipit Central Elementary School, Agusan Del Norte, Philippines \\ ${ }^{3}$ Cebu Doctors University
}

\begin{abstract}
Given that distance education has been primarily based on the use of digital technologies such as email, online courses and document-sharing platforms, the crisis has highlighted the need to develop teachers' digital literacy. This study explores the experiences of the tertiary Physical Education teacher's educational technology in new normal UM Tagum College and Cebu Doctors' University. Six college physical education teachers participated in this study. A qualitative case study method employing phenomenological procedures to collect and analyzed the data was used. The challenges encountered by the Physical Education teachers in educational technologies include online teaching modalities/platforms used concerns, lack of access to the internet and unavailability of technological tools and gadgets. meanwhile, the coping mechanisms of physical education teachers involve retooling on teachers, possess a positive outlook, and provide alternative means. This paper will serve as a reference for future studies related to any pandemic that might come in the future, specially in the educational sector of our country. Implementing agencies such as DepEd, TESDA and CHED should conduct studies related to the planning and implementation strategy, survey online platforms to students and teachers, assessing online learning systems to schools, project proposals and development of instructional materials, and many more.
\end{abstract}

Keywords: COVID-19 Pandemic; Educational Technology; Physical Education teachers; Experiences

\section{Introduction}

The COVID-19 pandemic has changed the world. From what is then the normal to what is now the so called the new normal. Due to the character of the virus, particularly how it's transmitted, it's a profound impact on the economic, political, cultural, and academic landscapes of societies across the world. Several institutions were temporarily closed to help contain the spread of the virus and help reduce the infection. (UNESCO, 2020). Responses like community lockdown and community quarantine of several countries have led students and teachers to review and work from home, leading to the delivery of online learning platforms (Crawford, et.al, 2020).

The current situation has led to the implementation of the so-called "new normal educational policy" to address and respond to the current issues and concerns in this time of pandemic. Agencies concerned have implemented policies to continue teaching activities from homes through the use of information and communication technologies to bridge the gap of the learners on their educational needs. These are online learning platforms, like google, TV broadcasts, guidelines, resources, video lectures, and online channels 
were introduced (UNESCO, 2020 ). The Philippines is within the method of adapting to the new normal kind of education at this, and continuous innovations of educators and active involvement of other stakeholders are the driving force for its success (Dangle, et al 2020).

Responding to the decision of WHO, the Department of Education (DepEd, Philippines), created a series of DepEd Memorandum (DM) No. 15, 21, 23, 31 and 34 within the half-moon of 2020 entitled "Creation of a Task Force for the Management of Department of Education Response to Novel Coronavirus Acute Respiratory Disease (2019-nCoV ARD)" (Department of Education, 2020a). The DepEd, Philippines, also created a learning website called DepEd Commons catering for Alternative Learning School (ALS) students, Out-of-School-Youth (OSYA), regular learners from Kindergarten to Grade 8. The online learning hub is available both for public and private schools all over the country. The website aims to strengthen education anytime and anywhere, suitable for learners who have access to the web using equipment like smartphones, tablets, laptops, and desktop computers (Department of Education, 2020b).

The implementation of online learning posed different risks, problems, and challenges to both the teachers and students, especially in higher education institutions (HEIs) (Bao, 2020). In the Philippines, there are 10,794 cases as of May 11, 2020 and it remains increasing (DOH, 2020), with quite four million cases worldwide (Worldometer, 2020). In response to those situations, educational leaders decided to adopt the new normal in education. At the essential education, the Department of Education (DepEd) are going to be implementing the training Continuity Plan (LCP), which can be in effect academic year 2020-2021 and classes will open on August 24, 2020 rather than June 2020 (DepEd, 2020). In the education sector, the Commission on education, HEIs got freedom and can implement available distance learning, e-learning, and other alternative modes of delivery to students (CHED, 2020).

Given that distance education has been based on digital technologies like email, online courses, and document-sharing platforms, the crisis has highlighted the need to develop teachers' digital literacy. While the utilization of digital tools is an integral a part of the professional skills expected of teachers and lots of teachers have already been using these tools (e.g., video), many teachers still lack the specified knowledge, skills and tools to style quality online learning material. Similarly, many students cannot independently use technologies. As a result, teachers during the crisis have had to play the twin role of coaching students about technologies with technologies.

This research aims to explore the experiences of Physical Education teachers in educational technologies in the new normal. Since no other study has been done on the problems that Physical Education faces in State Colleges and Universities, the findings can be seen as a foundation for future research and to help revitalize physical education classes. The challenge of providing quality, equitable and affordable education for all students would be a new standard in education and enhancing educational preparation and health. Therefore, this study paper has been drawn up to have a clear perspective on the current normal in education.

\section{Purpose of the Study}

The study's main purpose is to explore the experiences and challenges encountered by the Physical Education teachers on educational technology in new normal in tertiary level during the second semester academic year 2020-2021.

Specifically, the study sought to answer the following queries:

1. What are the challenges encountered by Physical Education teachers on educational technology in new normal?

2. What are the coping mechanisms of PE teachers in using the educational technology? 


\section{Method}

The aim of this study was to learn about the difficulties that teachers face when teaching Physical Education, as well as approaches that can help students excel in school and in society. Where the nature of the research questions necessitates exploration, a qualitative approach is needed (Stake, 1995). To gain a detailed understanding of what is going on in relation to the subject, qualitative research questions often begin with how or what (Patton, 2002; Seidman, 1998). The data was obtained and analyzed using a qualitative case study approach focused on phenomenological procedures. The study "turned to the essence of lived experience" of research participants' online physical education classes, exploring the experience of conducting these classes, discussing and reflecting on their efficient activity and difficulties encountered therein.

\section{Participants}

The participants of this study were the PE teachers from the tertiary level particularly from UM Tagum College and Cebu Doctors' University. Participants were purposively selected for this study. Raagas (2010) suggested that a purpose sampling of five to twenty individuals would be used in the phenomenological study. The selection of 6 teachers teaching Physical Education subjects in the tertiary level in an online setting served as the participants. The identities of these participants were held confidential for compliance with research standards. The participants communicated and elaborated on this phenomenon daily (Moscovici, 1988) as part of their undertakings. These teachers were chosen as participants on the confidence and trust that they could give helpful information that this study required.

\section{Instrument}

The primary instrument used in this study was an interview schedule focusing on the challenges encountered by the PE teachers on educational technology in new normal. Data were collected in stages, using informal, conversational, and semi structured interviews to collect in-depth information from the participants. This kind of interview technique helped them be at ease and comfortable in answering the questions. The data were analyzed according to standard protocols for evaluating observation objects and indicators (Braun and Clarke, 2006).

\section{Data Analysis}

This study used Thematic analysis in analyzing the data. Thematic Analysis is a method of analyzing qualitative data. It is usually applied to a set of texts, such as interview transcripts. The researchers closely examine the data to identify common themes topics, ideas and patterns of meaning repeatedly. This process was originally developed for psychology research by Virginia Braun and Victoria Clarke. However, thematic analysis is a flexible method that can be adapted to many different kinds of research.

\section{Results and Discussions}

\subsection{THEMES ON THE EXPERIENCES OF PE TEACHERS}

\section{Theme 7. 1.1 Online Teaching Modalities/Platforms used Concerns}

Professors are now using a range of tools to offer course content. They are teaching their courses using online educational sites, videoconferencing tools, and social media. (Patricia, 2020). Respectively, they 
can exchange notes and interactive tools related to their courses with students using online educational platforms. Students can send in assignments and

professors can keep track of their students' progress using online educational modalities.

"One of our online learning platforms, quipper, was needed by the school.

Since it is a bit difficult and needs a good internet connection, this platform is inconvenient for us teachers as well as my students. That is why I need to learn other online learning tools that are more appropriate for me, and so that my students do not have to pay more money to attend online classes. Facebook Messenger, Google Meet, Google Shared Drive, and Google Classroom are the applications I use the most. (Participant 003)

Lederman (2020) correctly indicated that, as a result of the COVID-19 crisis, both teachers and students feel compelled to accept the digital academic experience as the summum bonum of the online teaching-learning process. Through digital intelligence (DQ Institute, 2019) teachers can cater children's digital skills which are on the brink of cyber risk into the educational opportunities to get success in future ventures particularly in this pandemic where children are wholly dependent on online teaching. This study shows that teachers were trained by institutions who gained hands-on experiences. On the part of the teachers, it was an arduous task for them to use new instructional strategy and online modalities. At the very onset of the Teachers expected to connect with their students using several online channels that were convenient for them and their students. However, as the lockdown time was steadily extended, teachers noticed that Google Meet, Facebook Messenger, Google Classroom, and Google Shared Drive were adequate online resources for providing quality education. Despite the fact that teachers were educated on how to use Moodle to perform classroom activities, other online platforms were ultimately explored due to Moodle's complexity

\section{Theme 7.1.2 Lack of Access to Internet}

According to a Sunstar report from 2020, public and private school teachers must adapt to online learning. They shared reservations about internet-based education, citing ongoing issues with sluggish connections. It validated the report in Mayol (2020) that a strong internet access is a major problem in the delivery of instruction during the pandemic, since not all the Filipino families can afford to buy and secure stable internet connection. Moreover, the result also justified the report of Akamai (2017 as cited in Tria, 2020), that among the Asian countries, Philippines ranks the lowest in terms internet connectivity.

"When I conduct online classes, the internet connection at the office is weak, which makes it difficult to deliver the lesson online." (Participants 001)

The fact that the majority of faculty members had a somewhat stable Internet connection and only a few had a very stable connection may have contributed to their apprehension toward online education. Even among college students, Internet access remains a problem (Oducado, R.M.F., 2019). The study revealed that poor internet connectivity has been a problem in the country since the outbreak of the pandemic until the need to switch to online education became a pressing necessity. The majority of professors struggle with online classes because their internet connection is so poor. To support online education, it is suggested that faculty be provided with more resources and technology infrastructure. Furthermore, all faculty members should be granted a data allowance so that they can purchase high-speed internet connections.

\section{Theme 7.1.3 Unavailability of Technological Tools and Gadgets}


The online platforms adapted by different educational institutions in the country require technological tools and gadgets such as personal computers, laptops, tablets, and smart cellphones. Virtual Platforms also involves the use of internet access in most of its features through Wi Fi modems, internet fiber connections, and mobile data plans. Unavailability of these tools would lead to issues and concerns regarding the delivery of the teaching services which could contribute to the challenges experienced by P.E. teachers in teaching Physical Education during COVID-19 Pandemic. For instance, as conveyed by the informants, the absence of gadgets such as cellphones and laptops and WIFI modem which are considered as the common tools needed for the online learning makes it hard for them to perform well in teaching. They finds it hard to communicate with their students virtually since they are not capacitated with the needed tool for doing so.

"for the teacher, it's hard because we do not have our own WIFI and our own gadget" (Participant 006)

"even if I'm trying to reach to them, the problem is, they do not have cellphones" (Participants 002)

The dilemma brought about by the unavailability of the technological tools amongst our students simply implies that this challenges as experienced by the Physical Education teachers needs a serious intervention, the uniform of entries from the informants is a manifestation that mitigating actions must immediately be planned out so Physical education teachers will be able to perform our duties with the best of our ability and to be able to offer it to all our students and not just to chosen majority who can afford the technological tools.

The unavailability of the necessary technological tools affects both the first two themes that were discussed previously. Firstly, the availability of internet connections, whether strong or weak, is deemed useless without technological tools such as gadgets, smartphones, and personal computers. The use of the internet on online education needs a hardware medium where all its processes and features can be implemented. Secondly, the technological capabilities of the teachers and the students or the lack of it will not matter if they do not have the needed tools to put their skills into use. Online manipulative abilities, like the internet connections, need hardware where all the skills will be used. A teacher will not be able to teach and connect with their students if they do not have the necessary technological tools to mediate in the process and vice - versa.

\subsection{THEMES ON COPING MECHANISMS OF PE TEACHERS OF USING EDUCATIONAL TECHNOLOGY}

\section{Theme 7.2.1 Retooling on Teachers}

Technology has been viewed as a method, rather than a tool to facilitate and support teaching, and not the other way around, and it is sometimes assumed that if computers are placed in the hands of teachers, these devices will transform teaching.

\section{"I joined webinars about strategies in using educational technology" (Participant $005)$ \\ "The administrator gave us retooling training in our school” (Participant 004)}

Without a doubt, technology will continue to permeate in the language classroom and self-learning environments, and the debate as to its efficacy in enhancing learning will rage on on both sides of the issue. Nevertheless, the fact that remains at the core of the issue is how to integrate technology in sound-pedagogical 
ways, and Sparrgrove (2009, p. 11) summarized these observations when he stated that in the end, "it is pedagogical innovation that will define technology integration effectiveness."

\section{Theme 7.2.2 Possess Positive Outlook}

Teachers have always played a vital role in introducing reform-based innovations (e.g., online or virtual teaching, distance education, flexible learning). According to Semerci and Aydin (2018), attitude is a factor that affects an individual's actions based on his feelings and thoughts.

"I need to find out how to resolve the obstacles I've faced, because if I don't, I am still the one affected. I am a teacher who likes to think positively. I still strive to remove the bad and negative stuff in my life, and I believe this has helped me resolve my difficulties with my teaching. I am concentrating on being positive and doing what is right, healthy, and beneficial to myself." (Participant 001)

It is accentuated that attitude has come to be considered the level of positive or negative effect related to a specific object or belief. Huang and Liaw (2005) argue that teachers' positive attitudes towards their competence in using the new normal will affect how they deliver knowledge to the students. In the study of Keeton (2004), he found out that teachers have positive attitudes towards the online instructional resources that they use, which they believe is significant in creating an online environment that stimulates learning to the students. This is somewhat related to the findings of Keeton (2004) and Gasaymeh (2009) that faculty members have a moderately favorable attitude toward virtual teaching. The result of the present study is a good indication as Keeton (2004) explained that the positive attitude of teachers toward virtual teaching will help build a positive online environment. The teacher's positive attitude will provide a virtual setting beneficial to students that may probably motivate online learning.

\section{Theme 7.2.3 Provide Alternative Means}

The pandemic forced various institution to suddenly modify their workflow strategies and adopt new technologies. In most cases, these organizations did not get enough time to reflect upon how the new strategies and the associated technologies should be introduced and integrated to their existing setup (Carroll $\&$ Conboy, 2020). Provide alternative modes of learning and education in education institutions, and put in place equivalency and bridging programs, recognized and accredited by the state in times of emergency situations (R. H. Huang et al., 2020).

"What we need is to understand the circumstances as well as provide alternative methods of completing tasks. I provide a range of teaching methods that do not require a class to be set up online." (Participants 003)

Much of teaching and learning in an online environment is similar to teaching and learning in any other formal educational context (Anderson, 2011b). Online learning and teaching involve a diverse array of tools, resources, pedagogical approaches, roles, organizational arrangements and forms of interaction, monitoring and support-with many possible combinations of substitution and integration (Bates and Poole, 2003; Bullen and Janes 2007; Bach, Haynes and Smith 2007). This study implies that there are commonalities on the problems or challenges that teachers teaching Physical Education amidst pandemic. Hence, it is important for the Physical Education teachers to have an open dialogue with fellow PE teachers and eventually share their sentiments and their possible intervention to educational authorities, Unit Chair, Deans, 
VPAS so that more experts will be able to share insights on how to solve those problems.

\section{Implications}

This paper highlights experiences and coping mechanisms of PE teachers using educational technology. If one thing becomes clear, more organized research is needed to contribute to a body of theoretical and practical knowledge for teacher education to use in the changing educational landscape. This paper will serve as reference for future studies related to any pandemic that might come in the future specially in the educational sector of our country. Implementing agencies such as DepEd, TESDA and CHED should conduct studies related to the planning and implementation strategy, survey online platforms to students and teachers, assessing online learning systems to schools, project proposals and development of instructional materials, and many more.

\section{References}

Bao, W. (2020). COVID-19 and online teaching in higher education: A case study of Peking University. Human Behavior and Emerging Technologies. https://doi.org/10.1002/hbe2.191

Barreara, K., Jaminal, B., \& Arcilla, F. (2020). Readiness for flexible learning amidst COVID-19 Pandemic of Saint Michael College of Caraga, Philippines. SMCC Teacher Education Journal (2) 1-15. https://www.researchgate.net/publication/344374652_Readiness_for_Flexible_Learning_amidst_CO VID-19_Pandemic_of_Saint_Michael_College_of_Caraga_Philippines.

Baticulon,R., Alberto, N., Barron, M., Mabulay, R., Rizada, L., Sy, J., Tiu, C, Clarion,C., \& Reyes. J. (2020). Barriers to online learning in time of COVID-19: a national survey of medical students in the Philippines. medRxiv. https://doi.org/10.1101/2020.07.16.20155747.

Braun, V., \& Clarke, V. (2006). Using thematic analysis in psychology. Qualitative Research in Psychology, $3(2), 77-101$

CHED. (2020). CHED COVID-19 ADVISORY NO. 3. Retrieved from https://ched.gov.ph/wpcontent/uploads/CHED-COVID-2019-Advisory-No.-3.pdf

Crawford, J., Butler- Henderson, K., Jurgen, R. Malkawi, B.H., Glowatz, M., Burton, R., Magni, P., Lam, S.

( 2020 ). COVID- 19: 20 Countries Higher Education Intra-period Digital Pedagogy Responses. Journal of Applied Learning and Teaching, 3

Dangle, Y. \& Sumaoang, J. (2020). The implementation of modular distance learning in the Philippine secondary public schools. $3^{\text {rd }}$ International Conference on Advanced Research in Teaching and Education. https://www.dpublication.com/wp-content/uploads/2020/11/27-427.pdf.

Department of Education. (2020a). Creation of a Task Force for the Management of Department of Education Response to Novel Coronavirus Acute Respiratory Disease (2019-nCoV ARD). Retrieved from https://www.deped.gov.ph/category/issuances/depedmemoranda/

Department of Education. (2020b). Towards A Sustainable and Working DepEd Commons Part II: A Framework. Retrieved from: https://commons.deped.gov.ph/depedcommons-framework.pdf

Gallagher S. (2012) What Is Phenomenology? In: Phenomenology. Palgrave Philosophy Today. Palgrave 
Macmillan, London. https://doi.org/10.1057/9781137283801_2

Strauss, A.; Corbin, J. Basics of Qualitative Research: Grounded Theory Procedures and Techniques, 2nd ed.; Sage: Thousand Oaks, CA, USA, 1998.

UNESCO. ( 2020 ). COVID- 19 Educational Disruption and Response.

Worldometer. (2020). Coronavirus Update (Live): 4,254,131 Cases and 287,257 Deaths from COVID19 Virus Pandemic - Worldometer. Retrieved from https://www.worldometers.info/coronavirus/ 